"The moderating effect of skills development transfer on organizational commitment - a case-study of Free State TVET colleges"

AUTHORS

ARTICLE INFO

DOI

RELEASED ON

JOURNAL

FOUNDER

\section{Tshedi Naong}

Tshedi Naong (2016). The moderating effect of skills development transfer on organizational commitment - a case-study of Free State TVET colleges. Problems and Perspectives in Management, 14(4-1), 159-169. doi:10.21511/ppm.14(4-1).2016.04

http://dx.doi.org/10.21511/ppm.14(4-1).2016.04

Friday, 23 December 2016

"Problems and Perspectives in Management"

LLC "Consulting Publishing Company "Business Perspectives"
NUMBER OF REFERENCES

0

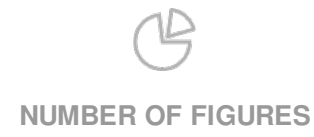

0

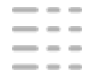

NUMBER OF TABLES

0

(C) The author(s) 2023. This publication is an open access article. 


\title{
The moderating effect of skills development transfer on organiza- tional commitment - a case-study of Free State TVET colleges
}

\begin{abstract}
One of the legacies of Apartheid South Africa which has ominous consequences for the economy, is the insidious dire skills shortage for majority of the citizens. Compelling government to embark on an intensive wholesale skills development to ameliorate and stimulate the general economic performance. This paper therefore, explored the relationship between employee organizational commitment and skills development transfer. A longitudinal study, with a pre- and post-quasi experimental research design was adopted in this paper employing Organizational Climate (OC) instrument to collect data from 59 randomly selected TVET college employees. The study revealed significant correlation between organizational commitment and skills development transfer. For example, appreciative of the access to training opportunities, involvement and frequency of training, sense of belonging, an indicative of the affective organizational commitment, with meagre $23 \%$ indicating intention to use acquired new skills to look for greener pastures elsewhere. This paper attempts to assist organizations better tailor their training provision to align it with certain desirable behavioral patterns, so as to enhance organizational commitment and reduce the turnover rate of staff.
\end{abstract}

Keywords: TVET colleges, skills transfer, organizational commitment, staff turnover, performance JEL Classification: D23.

\section{Introduction}

Without a well-trained and motivated workforce, organizations cannot be successful (Cronje, du Toit, Marais \& Motlatla, 2006, p. 222). Getting the best out of employees has become a daunting task for organizations today, as most of them always ponder about measures of ensuring a maximum performance from employees. Generally speaking, employee performance depends on a large number of factors, such as motivation and commitment, appraisals, job satisfaction, training and development and so on, but this paper focuses only on employee commitment, as it has been shown to influence to a significant degree the organizational performance (Dobre, 2013). Similarly, Champathes (2006) states that as when employees would be more developed, they would be more satisfied with the job, more committed with the job and the performance would be increased. When employee performance would increase, this will lead to the organization effectiveness. As Kalimullah (2010) suggested, a motivated employee has his/her goals aligned with those of the organization and directs his/her efforts in that direction. In addition, these organizations are more successful, as their employees continuously look for ways to improve their work. Lesabe $(2007$, p. 35) claims that no organization in today's highly competitive world can perform at peak levels unless each and every employee is committed to its objectives and strategic goals. White and Bryson (2013, p. 385) and GouldWilliams (2007) further add that there is a growing consensus that HRM practices influence employee attitudes and work-related behavior with positive or

(C) Tshedi Naong, 2016.

Tshedi Naong, Professor, Department of Business Management, Faculty of Management Sciences, Central University of Technology, Free State, Bloemfontein, South Africa. negative organizational commitment. Kooij, Jansen, Dikkers and de Lange (2010) suggested that high commitment HR practices including training and development are aimed at eliciting a strong bond of attachment to the organization. Given the established relationships between organizational commitment and employees' motivation, job performance, and turnover levels ( $\mathrm{Ng} \&$ Sorensen, 2008), efforts to ensure comprehensive training may serve as an important first step in promoting a variety of other desirable individual-level outcomes. Further, at the organizational level, this involvement in developing more committed employees may be recognized as one means by which HRD practices contribute to a firm's achieving competitive advantage (Bulut \& Culha, 2010). In this sense, seemingly small decisions made by HRD professionals involving the comprehensiveness of training programs may have far-reaching implications.

In order to judge better the effectiveness of training it has been suggested that its relationship to organizational commitment be examined directly. The implementation of effective HR practices has been shown to play an important role in building and maintaining the commitment of employees towards the organization (Allen et al., 2003). Similarly, Chaudhuri (2012) adds that numerous previous studies have shown that HR practices influence organizational performance through individual work related attitudes, such as commitment, motivation, and satisfaction (Kooij, Jansen, Dikkers, \& DeLange, 2010). Beyond doubt, retaining employees is important for firms to generate organizational success. Generally, firms invest in employees to increase the knowledge and productivity in the firm, but also to keep the employee satisfied and decrease their mobility. 
Retaining important employees (i.e. decreasing turnover intentions) can be a critical success factor for receiving competitive advantage.

The impact of training on organizational commitment has not been so widely researched. The research interest in the relationship between HRD and organizational commitment continues (Bambacas \& Bordia, 2009; Bulut \& Culha, 2010; Fornes, Rocco $\&$ Wollard, 2008) and can never cease as long as the causes for below performance of staff continue unabated. It is being said that current international human resource management research has a strong focus on how organizations can improve the organizational commitment of employees (Malhotra, Budhwar \& Prowse, 2007). The South African skills development landscape aggressively endeavors to reverse the legacy of Apartheid in favor of advancing optimal economic performance. All sectors of the economy had to make a drastic mind shift regarding human capital investment. Business organization had to embrace a culture of constant reengineering, i.e. creativity and innovativeness, a hallmark of a learning organization to remain competitive. Congruent to the argument by Van Rensburg (2004) states that business organizations today are striving to become world-class organizations and compete globally. Therefore, for organizations to become a world-class organization, they need committed (Lesabe, 2007, p. 35; Roodt, 2004) as well as adequately skilled employees. Suffice to say, the quality of an organization irrespective of the sector, to a large degree is determined by the quality of people it employs. It stands to reason therefore, that success for most organizations depends on finding the employees with the skills to successfully perform the tasks required to attain the company's strategic goals' (Hameed \& Waheed, 2011, p. 225). Dobre (2013) asserts that the sources of low productivity are not only related to wages, but also include the lack of technical and management skills. To improve performance, an organization or a manager will have to identify two categories of people. First, that motivation is fine, but whose skill or ability needs developing, and second, those ability and skill levels are fine but who lack motivation and commitment (Dobre, 2013).

Given this, the success of the capacitation endeavours for the Technical and Vocational Education Training Sector (TVET) specifically the Free State province staff needed to be predicated on solid premise/s. Devising a balance between optimal performance and sustained employee motivation and commitment hinges on deliberate impact driven intervention strategy. This sector had in the recent past endured numerous disruptions from both students and staff. Sig- nalling discontentment with disastrous effect on motivation, commitment and ultimately performance/productivity. The visionary leadership of the TVET top management led to availing access of skills development opportunities for staff since the end of the unrest which might positively impact commitment and performance. The benefit to organizations from high levels of organizational commitment has been widely researched (Gamble and Huang, 2008). Research on the effects of skills development has shown a consistent, positive relationship between employee commitment and reduced turnover of staff amongst others. For example, results of a multilevel regression analysis support a direct relationship between perceived training comprehensiveness and organizational commitment (Ehrhardt, Miller, Freeman \& Hom, 2011). The contention in this paper is that, the significance of staff training needs to be viewed as the true investment in human capital which has the potential to guarantee future rewards and sustainable competitive advantage for organizations. The underlying hypothesis of this study is that training can enhance not only the effort and ability of an individual's performance, but also their commitment to the organization.

\section{Organizational commitment in perspective}

Commitment can be described as an individual's desire to remain focused and attached to his work. Mowday, Steers and Porter (1982) had defined commitment an employee's willingness to work positively in an organization and his continuance to work for it. While organizational commitment (OC) is "a state in which an employee identifies with a particular organization and its goals, and wishes to maintain membership in the organization" (Miller, 2003, p. 73). The concept of organizational commitment has attracted considerable interest in an attempt to understand and clarify the intensity and stability of an employee's dedication to the organization (Lumley, 2010). Meyer and Allen (1997, p. 3), suggested that a "committed employee is one who will stay with the organization through thick and thin, attends work regularly, puts in a full day (and maybe more), protects company assets, and who shares company goals". Although there is minimal consensus on the antecedents of organizational commitments, we posits that more often than not, employee commitment is a consequence of an interplay of mainly effort (i.e. through skills development transfer), job satisfaction, and prevailing organizational climate. Similarly, Newman, Thanacoody \& Hui $(2011$, p. 01) from their own studies add that "research supports the notion that it (i.e. commitment) is related positively to a variety of desirable outcomes including job satisfaction and performance, and to a decline in an employee's intention to leave. OC is a core issue for the man- 
agement of any organization, because it is directly related to the performance of employees and is therefore treated as an issue of great importance (Jaramillo, Mulki \& Marshall, 2005). The most popular and widely used model of organizational commitment is the one conceptualized by Allen and Meyer (1993), which has a three component structure, namely; affective, continuance and normative commitment.

Current international human resource management research has a strong focus on how organizations can improve the organizational commitment of employees (Malhotra et al., 2007; Newman, Thanacoody \& Hui, 2011, p. 02). An endeavor to fully comprehend exactly which factors contribute to employees' organizational commitment, remains both topical and elusive at the same time. Literature on the construct of "organizational commitment" indicates that this construct can be described from an attitudinal, behavioral and motivational perspective, for example Morrow (1993) describes organizational commitment as characterized by attitude and behavior. An attitude that reflects feelings such as attachment, identification and loyalty to the organization as an object of commitment (Morrow, 1993). Miller and Lee (2001) indicates that from the motivational perspective, $\mathrm{OC}$ is characterized by employees' acceptance of organizational goals and their willingness to exert effort on behalf of the organization. Equally, Werner (2007, p. 335) indicates that organizational commitment as a "work-related attitude seems to be closely related to performance and turnover of employees".

\section{Training and its effect on organizational com- mitment}

Naong (2014, p. 370) alludes that documented literature continue to argue that training and development is seen as a key factor in making it possible for an organization to achieve its strategic, business and operational goals (Carrell, Elbert, Hatfield, Grobler, Marx \& van der Schyff, 2000, p. 308), and therefore training outputs should emphasize performance (Yamnill \& McClean, 2001). Congruent to this view, Sheri-lynne, Parbudyal (2007) add that employee development is becoming an increasingly critical and strategic imperative for organizations in the current business environment. This performance is a factor of an employee's commitment and effort. Recent literature has extensively reported on the pervasive relationship between training and commitment (Owens, 2006; Al-Emadi and Marquardt, 2007) for instance, Bartlett (2001), Ahmad and Bakar (2003) state that training provision leads to improvements in organizational commitment. Newman et al. (2011, p. 01) add that the results of their survey highlight the importance of training as a tool to enhance the affective organizational commitment of employees, and reduce turnover. Similarly, Benson (2006) found a significant and positive effect between on-the-job training and organizational commitment.

The critical role a skilled and knowledgeable workforce can play in securing competitive advantages in both local and international markets can never be over-emphasized (Naong, 2010, p. 1063). Training is often considered as one of the most important investments in terms of enhancing intellectual capital, which is vital for the organization's competitive sustainability (Bulut \& Culha, 2010). Without doubt, training generates benefits for the employee knowledge, skills, ability, competences and behavior (Archieve, 2008; Benedicta, 2010; Dabale, Jagero \& Nyauchi, 2014). Conversely, organizations across sectors in South Africa have neglected to invest in their employees to equip them with the necessary skills for the challenges of our modern, globally competitive world (Swanepoel, 2000, p. 493), a consequence of the legacy of Apartheid. The South African government laments that the market has failed the economy, with the demand for skills far outweighing the supply (RSA, n.d.). Drastic measures to eliminate the devastating impact of the legacy of Apartheid became national inperative. Training at various economic sectors gained priority, hence this paper focused on the TVET sector to establish the effect of training received on some organizational behaviors of staff.

Naong (2010) claims that the South African Skills Development Act (2006) legislation is a "window of opportunity" that can be effectively used to improve organizational skills level, competencies, develop tailor-made training programs' that meet specific company needs and develop a pool of skills essential for the optimal organizational performance. Additionally, Benson (2006) found that training has a significant and positive influence on organizational commitment, and that organizational commitment has a significant and negative effect on turnover intentions. This leads to the important role of organizational commitment that might also occur as a result of offering training. Dabale, Jagero and Nyauchi (2014, p. 67) allude that employees that are trained by their organizations are more involved to the assigned tasks. (Becker, Antuar \& Everett, 2011). The employees who are very committed to the job assignments are an essential part of their live. After their better performance, they feel satisfaction, this nature of job involvement deemed towards self-esteem (Bright, 2008). After being trained personnel become highly motivated for doing innovative tasks, when they feel high involvement in their jobs (Chevalier, 2007). 


\section{Conceptualization and theory}

Amongst a myriad of theories that can be employed to unpack the commitment phenomenon, the most common theoretical frameworks that turn to feature strongly in this field are social exchange, psychological contract, and human capital theories. This paper is built exclusively on both work motivation theory and the social exchange theory. Where the former posits that firms achieve higher performance by investing in certain forms of HRM practice that help fulfill intrinsic work values and thereby influence employees' attitudes to their jobs and to the firm in a positive direction (White et al., 2013, p. 387) while the social exchange is based on an implicit agreement between employee and the employer, referred to as a psychological contract (Rousseau, 1995). Psychological contracts are governed by the norm of reciprocity and have been shown to play an important role in determining organizational behavior (Garrow, 2004). An extensive documented literature suggests that employees enhance their commitment towards the organization, when the organization meets their expectations as regards fulfilment of their individual needs (Malhotra et al., 2007). This social exchange is primarily initiated by organizations when they signal their willingness to care for employee interests (Gould-Williams, 2007) and the workforce reciprocate with positive attitudinal and behavioral responses helpful to their organization. Table 1 depicts relationship of training and $\mathrm{OC}-$ the conceptual framework.

Table 1. Moderating effect of skills development transfer on TVET college staff's OC

\begin{tabular}{|l|l|l|l|}
\hline $\begin{array}{c}\text { Dependent } \\
\text { variable }\end{array}$ & $\begin{array}{c}\text { Independent } \\
\text { variable }\end{array}$ & $\begin{array}{c}\text { Skills } \\
\text { transfer }\end{array}$ & \multicolumn{1}{c|}{$\begin{array}{c}\text { Post-training outcome } \\
\text { (resultant effect) }\end{array}$} \\
\hline $\begin{array}{l}\text { Organizational } \\
\text { commitment } \\
\text { (OC) }\end{array}$ & Training & $\begin{array}{l}\text { moderating } \\
\text { effect }\end{array}$ & $\begin{array}{l}\text { strong attachment } \\
\text { Improved staff morale } \\
\text { Reduced staff turnover } \\
\text { Improved performance }\end{array}$ \\
\hline
\end{tabular}

The results of this paper reported that availability and involvement in training has a strong relationship with both affective, while a sense of belonging with normative commitments. Table 1 depicts the underlying hypothesis of this paper, i.e. strong organizational attachment, improved staff morale and reduced staff turnover are consequences of an improved organizational commitment, which is further translated into improved performance. This view is confirmed by Bartlett (2001) when he retorts that training, like other HRM practices, is a useful vehicle to elicit desired responses which may include improved organizational commitment. Garrow (2004) further adds that research evidence suggests that training and development provision is taken as a sign by employees that their organization desires to enter into a social exchange with them. This creates a strong psychological bond between them and their employer.

\section{Problem statement and underlying hypothesis}

This paper is prompted by the general view that the success or failure of an organization to a large extent depends on the quality of human resources (Ekwoaba, Ikeije and Ufoma, 2015) practices. Exploring the relationship between employees' organizational commitment and skills development transfer is the primary focus of this paper. With a hypothesis that reads thus, "there is a significant relationship between employees' organizational commitment and skills development transfer, i.e. training" at the TVET colleges in the Free State Province. A cross-sectional survey was conducted on a randomly sample of 59 employees at four TVET Colleges in the Free State Province, South Africa. Correlational and multiple regression analyzes revealed a number of significant relationships between the two variables. The findings add new knowledge that can be used to improve organizational practices for the retention of valuable staff members in the TVET College sector.

\section{Expectancy theory as an instrument to validate the hypothesis}

Hypothesis: skills development transfer can enhance employee's behavioral issues, specifically, organizational commitment.

Our hypothesis is premised on the expectancy theory (Vroom, 1964) which is complemented by the reciprocity theory. The basic components of Vroom's (1964) model are Expectancy, Instrumentality, and Valence, hence the term V.I.E theory. An individual's motivational force to perform (effort) as determined by Vroom's (1964) Expectancy model, then, would be derived by multiplying his (E - P) expectancy times his $(\mathrm{P}-\mathrm{O})$ expectancy times his outcome valence. We contend that with necessary training (i.e. positive valence), one will be motivated to increase one's commitment and performance (i.e. effort) only if this will ensure (i.e. instrumentality) one the rewards (i.e. expectancy) that go with improved commitment resulting from training received. The emphasis is on effort $(\mathrm{E}-\mathrm{C})$ and commitment, i.e. by improving the relationship between effort and commitment through training, performance is likely to increase and staff turnover intentions eradicated.

\section{Methodology}

6.1. Research design. Kumar (2005) defines research design as a plan, structure and strategy of investigation to obtain answers to research questions or problems. In this paper, the research approach followed was mainly quantitative and descriptive in nature. Quantitative research is a numerical method 
describing observations of materials or characteristics (Creswell, 2014; Maree \& Pieterson 2007). A self-designed semi-structured questionnaire using a five point Likert rating scale was used to collect data from randomly sampled teachers. Leedy and Ormord (2010), MacMillan (2008) define a questionnaire as a set of questions on a form which is completed by the randomly selected respondents in respect of a research project.

A positivist paradigm, i.e. quantitative approach, in a form of a survey research design was adopted, and specifically the quasi-experimental research comparable pre-test post-test one group design, was used to carry out the objectives and to test the study's hypothesis (Leedy \& Ormord, 2010). A non-probability sampling technique, namely stratified random sampling, was used to solicit responses from respondents. In the research design, there is a measurement of a dependent variable, namely individual motivation, when no independent variable (pre-training) is present, and subsequently an independent variable is introduced, namely training, followed by a repeated measurement of the dependent variable at a later stage, i.e. post-training (Leedy \& Ormord, 2010). The study is longitudinal, spanning six to twelve months. Given the relatively small size of the sample population in this study, these findings can only provide an indication of how the respondents feel or perceive the role of training towards organizational commitment, without necessarily laying claim to any national representation.

6.2. Population and sampling size. The target sample population (i.e. $\mathrm{n}=104$ ) consisted of 59 randomly selected lower to middle lower level employees from four (4) TVET colleges (i.e. Motheo in Bloemfontein $(\mathrm{N}=20)$, Flavius Mareka in Sasolburg $(\mathrm{N}=13)$, Maluti in Bethlehem $(\mathrm{N}=15)$, and Goldfields in Welkom $(\mathrm{N}=11)$ in the Free State province of South Africa. There was specific reference to employees doing automatic (semi-skilled) and routine (skilled workers and supervisory management), excluding teaching staff. This classification is derived from Paterson's (1972) Decision Band Job Grading Model. According to this model, this category of workers belongs to grades "A", "B1" and "B", and does not necessarily take cognisance of performance management in daily routine jobs (Condrey, 2010, p. 32), unlike other workers in the higher echelon of the management hierarchy.
6.3. Data collection. A survey in the form of a semi-structured questionnaire was used to collect data from 59 respondents from four TVET colleges, and data were both causal and longitudinal, because the required data were collected before and after spanning over a period of 12 months. The developed questionnaire items were based in the main on the seminal work by Meyer, Allen and Smith's (1996) Organizational Climate (OC) measuring instrument. Their theory includes affective commitment, normative commitment and continuance commitment. The questionnaire comprised of two parts: Part A related to demographics data (namely, gender, age, qualifications, marital status, employed or not), while Part B - factual items as well as attitudinal and perception items regarding participants' views and perceptions regarding relationship between training and organizational commitment. Face validity and content validity were ensured in this paper as the contents of the questionnaires covered issues respondents are familiar with.

6.4. Data analysis. Presentation of the collected data was done using both inferential and descriptive statistics, using the computer software package, Statistical Package for the Social Sciences (SPSS, 2003). Pearson-product moment correlations and multiple regression analysis were performed to test the research hypothesis. To determine the reliability of the questionnaire, a factoranalysis procedure was used to investigate the construct validity of the $\mathrm{OC}$ instrument. The F-test was used to test whether there was a significant regression $(p \leq 0.05)$ between the independent and dependent variables. The alpha reliability coefficient for the 18 items of the questionnaire was 0.77 (see Table 1). Although the means are presented in the tables, significance is based on the ranks of the absolute values of the differences.

6.5. Factoring. Factor rotation was used to enhance the significance and reliability of the factors (Bartholomew, Knott, \& Moustaki, 2011). The purpose of rotation was to obtain the best out of the relevant factors. Thus, to obtain a factor matrix, the variables load as high as possible on a few factors, and have low loadings on other factors (Yong \& Pearce, 2013, p. 79). The varimax technique was used in the extraction of the first level factors, in order to maximize explained variance.

Table 2. Reliability analysis of "organizational commitment" measuring instrument

\begin{tabular}{|c|c|c|c|c|}
\hline \multicolumn{5}{|c|}{$\begin{array}{l}\text { RELIABILITY ANALYSIS - SCALE (ALPHA) } \\
\text { Item-total Statistics }\end{array}$} \\
\hline & $\begin{array}{l}\text { Scale mean if } \\
\text { item deleted }\end{array}$ & $\begin{array}{c}\text { Scale variance if item } \\
\text { deleted }\end{array}$ & $\begin{array}{l}\text { Corrected item- } \\
\text { total correlation }\end{array}$ & $\begin{array}{l}\text { Alpha if item } \\
\text { deleted }\end{array}$ \\
\hline Feel better qualified to do job & 30.0000 & 9.4118 & .1248 & .7625 \\
\hline Training must be more frequent & 30.0000 & 9.0588 & .2544 & .7484 \\
\hline
\end{tabular}


Table 2 (cont). Reliability analysis of "organizational commitment" measuring instrument

\begin{tabular}{|c|c|c|c|c|}
\hline \multicolumn{5}{|c|}{$\begin{array}{l}\text { RELIABILITY ANALYSIS - SCALE (ALPHA) } \\
\text { Item-total Statistics }\end{array}$} \\
\hline & $\begin{array}{l}\text { Scale mean if } \\
\text { item deleted }\end{array}$ & $\begin{array}{l}\text { Scale variance if item } \\
\text { deleted }\end{array}$ & $\begin{array}{l}\text { Corrected item- } \\
\text { total correlation }\end{array}$ & $\begin{array}{l}\text { Alpha if item } \\
\text { deleted }\end{array}$ \\
\hline Appreciate training investment made on me & 29.8333 & 8.5000 & .4078 & .7301 \\
\hline Training relevant to my day to day work & 29.8333 & 7.7941 & .6731 & .6943 \\
\hline Training received will lead to increased income & 30.2778 & 8.4477 & .4590 & .7242 \\
\hline Feel marketable after receiving training & 30.2222 & 6.7712 & .6136 & .6928 \\
\hline Inclined to look for greener pastures after training & 29.7778 & 6.7712 & .7353 & .6689 \\
\hline Training improved working relations & 29.6111 & 8.1340 & .5811 & .7087 \\
\hline Quantity and quality of work has improved & 30.0000 & 8.4706 & .2719 & .7535 \\
\hline Own confidence level has improved after training & 29.9444 & 9.7026 & .0130 & .7760 \\
\hline Loyalty/commitment to organization has improved & 30.2782 & 6.6127 & .6376 & .6767 \\
\hline Training has improved my ability to perform better & 30.2773 & 7.5866 & .7481 & .6726 \\
\hline Training has increased my chances for promotion & 29.9202 & 6.3811 & .5387 & .7424 \\
\hline Begun enjoying work since receiving training & 30.3228 & 9.7216 & .7261 & .6628 \\
\hline $\begin{array}{l}\text { Reliability Coefficients } \\
\mathrm{N} \text { of Cases }=12.0 \mathrm{~N} \text { of Items }=14 \\
\text { Alpha }=.7739\end{array}$ & & & & \\
\hline
\end{tabular}

6.6. Ethical considerations. Permission was sought from the management of the four TVET colleges and granted prior to distributing and administering the questionnaire. Respondents' consent was obtained, voluntarism, confidentiality and anonymity were assured.
6.7. Resultsand discussion. 6.7.1. Demographic data. The following demographic variables are discussed, namely, gender, age, highest qualification, job title, and work experience. All 59 participants consisted of $43.3 \%$ females and $56.7 \%$ males.

Table 3. Respondents' demographic variables

\begin{tabular}{|c|c|c|}
\hline Demographic variables & Frequency & Total sample $\%(n=59)$ \\
\hline \multicolumn{3}{|l|}{ Gender } \\
\hline Male & 30 & 56.7 \\
\hline Female & 29 & 43.3 \\
\hline \multicolumn{3}{|l|}{ Age } \\
\hline $21-35$ & 10 & 28.4 \\
\hline $36-45$ & 30 & 57.4 \\
\hline$>46$ & 19 & 14.2 \\
\hline \multicolumn{3}{|l|}{ Highest qualifications (tick only one) } \\
\hline Grade 12 & 0 & 0 \\
\hline First certificate/diploma/degree & 31 & 52.5 \\
\hline Honours/postgraduate diploma & 18 & 30.5 \\
\hline Master degree & 9 & 15.3 \\
\hline Doctorate & 1 & 1.7 \\
\hline \multicolumn{3}{|l|}{ Job title (core functions) } \\
\hline Staff level & 26 & 44.1 \\
\hline Supervisors & 18 & 30.5 \\
\hline Deputy campus managers or deputy-directors & 11 & 18.6 \\
\hline Campus manager or director & 1 & 1.7 \\
\hline Chief director & 2 & 3.4 \\
\hline Other & 2 & 3.4 \\
\hline \multicolumn{3}{|l|}{ Work experience } \\
\hline Between $1-3$ years & 8 & 13.6 \\
\hline Between 3 - 5 & 17 & 28.8 \\
\hline Between $5-10$ years & 16 & 27.1 \\
\hline Between $10-20$ years & 12 & 20.3 \\
\hline More than 20 years & 6 & 10.2 \\
\hline
\end{tabular}


The majority of the study population was in their mid-years $(57.4 \%)$, that is between $36-45$ years of age. Most respondents (i.e. 52.5\%) followed by $30.5 \%$, had either first degree or diploma and Honours or postgraduate diploma respectively. An aggregated total of more than $70 \%$ (i.e. $44.1 \%$ and
$30.5 \%$ ) dominated by respondents at staff/lower and supervisory level of their respective TVET colleges. Almost all respondents had more than reasonable and satisfactory work experience, a clear indicator of organizational commitment.

Table 4. Attitudinal and perception variables - post-training on organizational climate

\begin{tabular}{|c|l|c|c|c|c|c|}
\hline \multirow{2}{*}{ No. Post-training response items } & \multicolumn{3}{|c|}{ Respondents' rating/score (\%) } \\
\cline { 3 - 6 } & & $\mathrm{SA}=5$ & $\mathrm{~A}=4$ & $\mathrm{~N}=3$ & $\mathrm{D}=2$ & $\mathrm{SD}=1$ \\
\hline 1 & I feel better qualified to do my job after receiving training & 10 & 67 & 43 & 3 & 1 \\
\hline 2 & Training must be more frequent not a once off intervention & 68 & 83 & 11 & 5 & 0 \\
\hline 3 & I greatly appreciate training investment made on me & 43 & 73 & 4 & 0 & 0 \\
\hline 4 & I feel training was relevant and related to my day to day work & 0 & 68 & 47 & 11 & 8 \\
\hline 5 & Hope improved performance will translate to better income & 52 & 73 & 6 & 0 & 0 \\
\hline 6 & I feel far more marketable after receiving training & 16 & 59 & 21 & 4 & 0 \\
\hline 7 & I am inclined to look for greener pastures after receiving training & 10 & 36 & 19 & 52 & 0 \\
\hline 8 & Training improved my working relationship with fellow workers & 8 & 31 & 63 & 26 & 1 \\
\hline 9 & Quality of my performance has since improved & 19 & 71 & 39 & 2 & 0 \\
\hline 10 & Quantity of my outputs has increased due to training received & 21 & 53 & 59 & 9 & 3 \\
\hline 11 & My confidence level is much improved due to training received & 29 & 67 & 48 & 11 & 0 \\
\hline 12 & There is definitive improvement on my work commitment & 21 & 75 & 10 & 2 & 6 \\
\hline 13 & Training has improved my loyalty to my organization & 32 & 61 & 22 & 13 & 3 \\
\hline 14 & My organizational commitment has improved due to training & 29 & 73 & 12 & 8 & 3 \\
\hline 15 & Training has improved my ability to do my work better & 41 & 58 & 29 & 6 & 0 \\
\hline 16 & It helps increase my chances for promotion & 5 & 83 & 45 & 15 & 3 \\
\hline 17 & Training enables me to enjoy my work & 7 & 51 & 63 & 2 & 0 \\
\hline 18 & Understand and interpret organizational policies/ procedures better & 3 & 62 & 49 & 3 & 1 \\
\hline
\end{tabular}

Notes: strongly agree (SA); agree (A); neutral (N); disagree (D); and strongly disagree (SD).

The underlying hypothesis of this paper is that there is a significant relationship between skills development transfer and organizational commitment. Both access to training and involvement in training indicate a positive and significant relationship with commitment in general in Table 3. Similar findings were also reported by Bartlett (2001) and Ahmad and Bakar (2003) though they were very specific to both the affective and normative forms of work commitment. There is also a positive and significant correlation between the three elements of perceived benefits of training namely, (i) job related benefits - $(p<0.001)$, (ii) career re- lated benefits $-(p<0.001)$, and (iii) personal related benefits $-(p<005)$ from acquiring training. Surely, these findings relate directly to affective commitment, because it represents the feelings and expectations of the respondents regarding training. An indicator of loyalty and commitment to an organization. A high level of significance in the difference between mean score for the following variables was found; perceived access to training, training frequency, perceived benefits of training, total organizational commitment with special reference to affective commitment and lesser degree normative commitment as well.

Table 5. T-test results for gender

\begin{tabular}{|l|c|c|c|c|}
\hline \multicolumn{1}{|c|}{ Items $(\mathrm{n}=59)$} & Male $(\%)$ & Female $(\%)$ & Mean $(\%)$ & $p$-value \\
\hline Feel better qualified to do my job after training & 58.6 & 61.7 & 46.8 & $<.005$ \\
\hline Training must be more frequent than once off & 76.8 & 61.2 & 69.2 & $<.001$ \\
\hline I appreciate training investment made on me & 34.1 & 27.5 & 30.8 & $>.005$ \\
\hline Training relevant to my day to day work & 52.1 & 56.6 & 54.4 & $>.061$ \\
\hline Training received will lead to increased income & 39.9 & 53.7 & 46.8 & $<.001$ \\
\hline Feel marketable after receiving training & 62.7 & 35.3 & 49.0 & $<.005$ \\
\hline Inclined to look for greener pastures after training & 71.3 & 55.4 & 73.1 & $<.001$ \\
\hline Training improved working relations & 51.6 & 59.8 & 44.4 & $<.010$ \\
\hline Quality of performance has since improved & 56.4 & 63.8 & 61.2 & $<.001$ \\
\hline Quantity of performance has since improved & 51.9 & 66.3 & 59.7 & $<.005$ \\
\hline Own confidence level has improved after training & 83.1 & 77.0 & 53.5 & $<.001$ \\
\hline Definitive improvement on my work commitment & 73.9 & 89.2 & 66.4 & $<.001$ \\
\hline Loyalty/commitment to organization has improved & 51.4 & 57.2 & 31.3 & $>.076$ \\
\hline
\end{tabular}


Table 5 (cont.). T-test results for gender

\begin{tabular}{|l|c|c|c|c|}
\hline \multicolumn{1}{|c|}{ Items $(\mathrm{n}=59)$} & Male (\%) & Female (\%) & Mean (\%) & $p$-value \\
\hline My organizational commitment drastically improved & 58.2 & 63.1 & 52.1 & $<.001$ \\
\hline Training has improved my ability to perform better & 70.2 & 82.6 & 52.8 & $<.010$ \\
\hline Training has increased my chances for promotion & 78.3 & 62.9 & 63.9 & $<.001$ \\
\hline Begun enjoying work since receiving training & 51.7 & 59.4 & 49.7 & $>.721$ \\
\hline Better understand and interpret policies/procedures & 67.2 & 89.1 & 61.9 & $<.005$ \\
\hline${ }^{*}$ Multiple responses does not add to 100 percent & \multicolumn{5}{|l}{} \\
\hline
\end{tabular}

Notes: $* p<.05,{ }^{* *} p<.01, * * * p<.001$

Presented in Table 6 are respondents' expressed views on organizational issues impacting on or- ganizational commitment inclusive of the role of training.

Table 6. Means and standard deviations of critical training elements to promote organizational commitment

\begin{tabular}{|c|l|c|c|c|}
\hline No. & \multicolumn{1}{|c|}{ Statements (N=59) } & Mean & Standard deviation & Std. error mean \\
\hline 1 & I would like a conducive working environment, i.e. welcoming and friendly & 4.16 & .903 & .089 \\
\hline 2 & Clarity of purpose, i.e. goals to be achieved & 4.01 & .939 & .092 \\
\hline 3 & I will welcome training opportunities for career development & 4.33 & .911 & .101 \\
\hline 4 & Available opportunities for upward mobility & 4.19 & 1.119 & .117 \\
\hline 5 & A strong family culture i.e. deep-rooted team spirit & 4.11 & 1.066 & .144 \\
\hline 6 & Depoliticizing the organizational environmental & 4.35 & .939 & .121 \\
\hline 7 & A genuine empathy from management and colleagues & 4.21 & 1.071 & .019 \\
\hline 8 & Appreciation, i.e. recognition and reward system & 3.01 & 1.209 & .012 \\
\hline 9 & A conviction on firmness, fairness and consistency & 4.17 & .911 & .011 \\
\hline 10 & Entrenched culture of trust across organization & 4.12 & .901 & .010 \\
\hline 11 & Mutual respect and cooperation across the organization & 3.63 & 1.012 & .104 \\
\hline 12 & Support and guidance & 2.91 & 1.132 & .131 \\
\hline 13 & Others (e.g. orientation, mentoring, exemplary, etc.) & 3.72 & 1.010 & .114 \\
\hline
\end{tabular}

Table 6 revealed that over $60 \%$ of the respondents indicated a high level of satisfaction with their organizational commitment, with more females feeling the impact or benefit of training to their work commitment (Table 4). The result pattern was consistent across the first seven statements. An average mean score of 4.17 showed that the combined ratings of the organizational commitment were high in relative terms. Overall, mean rating of the couple assessment categories ranged from 4.16 to 4.35 on a five-point scale, indicating that the overwhelming majority of respondents perceived organizational commitment positively and, therefore, pertinent to the career development they envision. The high mean ratings also indicated that the majority of participants view training opportunities drastically increasing not only their chances for career development but also prospects for upward mobility or promotion. Previous work has suggested that perceptions of training might only be related to commitment when training is tied to career development (Riaz, Idrees \& Imran, 2013), a factor strongly alluded to by respondents.

Regarding the link between the organizational commitment and skills development transfer offered to the TVET college staff, the research found a strong link specially between the (i) frequency of training, (ii) perceived impact of training on individual performance, (iii) training enhancing prospects for promotion with and individual's organizational commitment. A mean score of 3.35 $(s d=1.397)$ and further down on a five-point scale meant a relatively low number of respondents are of the opinion that there is correlation between skills development transfer and organizational commitment. The findings therefore suggest that the skills development training is more apposite to be an appropriate moderator to organizational commitment.

\section{Recommendations and conclusion}

The findings of this paper is in tandem with myriad of existing documentary findings in the literature that skills development transfer have significant effect on organizational commitment. The bases of this paper is that firms offer training to employees to receive better company results, we contend that human capital development or training is a necessary catalyst to enhance organizational commitment and realize not only increased performance but also drastically reduce staff turnover intentions. Premised on the reciprocity theory, both in-depth literature study and empirical evidence confirmed the underlying hypothesis of this paper, indicating strong relationship between skills development transfer, (i.e. training) and organizational commit- 
ment. Adopting a culture of staff development has clear evidence of increased harvesting and sustained competitive advantage for organizations. Human capital development must always form an integral part of any organizational strategic agenda because a sustained optimal employee performance is a factor of staff effort, commitment and job satisfaction. Therefore, learning organization will always depend on strategic leadership for meaningful and sustainable organizational growth. Investment in human capital development is never a financial waste, but one of the novel way to secure the organization's future and promote economic growth.

It is in the best interest of every organization to put high premium on human capital development, because the impact of training on organizational commitment is immeasurable. Since the dawn of democracy and the dramatic insistence for organizations to uphold constitutional principle of fairness and equity, most South African organizations saw a high rate of staff turnover. Redress and compliance to legislation for example, affirmative action, increased mobility of staff especially the equity candidates, creating pressures and instabilities to human resource plans, practices and procedures. Elevating organizational commitment from the periphery to the strategic centre stage won't only minimize staff turnover, but also minimize conflicts between both employee and employer and foster camaraderie and culture of unity, empathy and team-spirit. Necessary ingredients to a sustained optimal performance and competitive advantage.

\section{References}

1. Ahmad, K.Z. and Bakar, R.A. (2003). The Association between Training and Organizational Commitment among White Collar Workers in Malaysia, International Journal of Training and Development, 7 (3), pp. 166-185.

2. Al-Emadi, M.A.S. \& Marquardt, M.J. (2007). Relationship between employees' beliefs regarding training benefits and employees' organizational commitment in a petroleum company in the state of Qatar, International Journal of Training and Development, 11 (1), pp. 49-70.

3. Allen, D.G., Shore, L.M. and Griffeth, R.W. (2003). The Role of Perceived Organizational Support and Supportive Human Resource Practices in the Turnover Process, Journal of Management, 29 (1), pp. 99-118.

4. Archieve, B. (2008). Effect of Training and Manpower Development on Productivity of Workers. New York, Harper and Row Publishers.

5. Bambacas, M. \& Bordia, P. (2009). Predicting different commitment components: The relative effects of how career development HRM practices are perceived, Journal of Management \& Organization, 15 (2), pp. 224-240.

6. Bartholomew, D., Knotts, M. \& Moustaki, I. (2011). Latent variable models and factor analysis: A unified approach. $3^{\text {rd }}$ ed. West Sussex, UK: John Wiley \& Sons.

7. Bartlett, K.R. (2001). The Relationship Between Training and Organizational Commitment: A Study in the Health Care Field, Human Resource Development Quarterly, 12 (4), pp. 335-352.

8. Becker, K., Antuar, N. and Everett, C. (2011). Implementing an Employee Performance Management System in a Nonprofits Organization, Nonprofits Management and Leadership, 21 (3), pp. 255-271.

9. Benedicta Appiah. (2010). The impact of training on employee performance: A Case Study of HFC Bank (GHANA) Ltd, pp. 15-17.

10. Benson, G.S. (2006). Employee Development, Commitment and Intention to Turnover: a Test of Employability policies in action, Human Resource Management Journal, 16 (2), pp. 173-192.

11. Bright, L. (2008). Does Public Service Motivation Really Make a Difference on the Job between perceptions of support and work attitudes: A meta-analysis.

12. Bulut, C. \& Culha, O. (2010). The effects of organizational training on organizational commitment, International Journal of Training and Development, 14 (4), pp. 309-322.

13. Carrell, M.R., Elbert, N.F., Hatfield, R.D., Grobler, P.A., Marx, M. \& Van der Schyf, S. (2000). Human Resource Management in South Africa. CapeTown: Maskew Miller Longman.

14. Champathes, M.R. (2006). Coaching for performance improvement: The coach model, Development and Learning in Organizations, 20 (2), pp. 17-18.

15. Chaudhuri, S. (2012). The Relationship between Training Outsourcing and Organizational Commitment. Available at http://www.academia.edu/1836209/The_Relationship_between_Training_Outsourcing_and_Organizational Commitment.

16. Chevailier, R. (2007). A Manager's Guide to Improving Workplace Performance. New York: American Management Association.

17. Condrey, S.E. (2010). Handbook of Human Resource Management in Government. 3rd Edition. 1056 p. August 2010.

18. Creswell, J.W. (2014). Research Design. $4^{\text {th }}$ ed. California. Sage publication.

19. Cronje, G.J. de J., du Toit, G.S. \& Motlatla, M.D.C. (2006). Introduction to Business Management. 6th Edition. Cape Town: Oxford University Press.

20. Dabale, WP., Jagero, N. \& Nyauchi, M. (2014). The Relationship between Training and Employee Performance: The Case of Mutare City Council, Zimbabwe, International Journal of Human Resource Studies, 4 (4), pp. 61-72. 
21. Dobre, O. (2013). Employee motivation and organizational performance, Review of Applied Socio-Economic Research, 5 (1), p. 53.

22. Ehrhardt, K., Miller, J.S., Freeman, S.J. \& Hom, P.W. (2011). An examination of the relationship between training comprehensiveness and organizational commitment: Further exploration of training perceptions and employee attitudes, Human Resource Development Quarterly, 22 (4), pp. 459-489.

23. Ekwoaba, J.O., Ikeije, U.U. and Ufoma, N. (2015). The impact of recruitment and selection criteriaon organizational performance, Global Journal of Human Resource Management, 3 (2), pp. 22-33.

24. Fornes, S., Rocco, T.S. \&Wollard, K.K. (2008). Workplace commitment: A conceptual modeldeveloped from integrative review of the research, Human Resource Development Review, 7 (3), pp. 339-357.

25. Gamble, J. and Huang, Q. (2008). Organizational Commitment of Chinese Employees in Foreign-Invested Firms, International Journal of Human Resource Management, 19 (5), pp. 896-915.

26. Garrow, V. (2004). Training and Development and the Psychological Contract, Training Journal, April, pp. 8-10.

27. Gould-Williams, J. (2007). HR Practices, Organizational Climate and Employee Outcomes: Evaluating Social Exchange Relationships in Local Government, International Journal of Human Resource Management, 18 (9), pp. 1627-1647.

28. Hameed, A. \& Waheed, A. (2011). Employee Development and Its Affecton Employee Performance A Conceptual Framework, International Journal of Business and Social Science, 2 (13), pp. 224-229.

29. Jaramillo, F., Mulki, J.P. \& Marshall, G.W. (2005). A meta-analysis of the relationship between organizational commitment and salesperson job performance: 25 years of research, Journal of Business Research, 58, pp. 705-714.

30. Kamalian, A.R., Yaghoubi, N.M. \& Moloudi, J. (2010). Survey of Relationship between Organizational Justice and Empowerment (A Case Study), European Journal of Economics, Finance and AdministrativeSciences, 24, pp. $165-171$.

31. Kamalian, A.R., Yaghoubi, N.M. \& Moloudi, J. (2010). Survey of Relationship between Organizational Justice and Empowerment (A Case Study), European Journal of Economics, Finance and Administrative Sciences, 24, pp. 165-171.

32. Kooij, D.T.A.M., Jansen, P.G.W., Dikkers, J.S.E., De Lange, A.H. (2010). The influence of age on the associations between HR practices and both affective commitment and job satisfaction: A meta analyzes, Journal of Organizational Behavior, 31 (8), pp. 1111-1136.

33. Kumar, R. (2005). Research Methodology: A Step by Step Guide for Beginners. 2nd Edition. London: SAGE.

34. Leedy, P.D. and Ormond, J.E. (2010). Practical Research: Planning and Design. $9^{\text {th }}$ ed. New Jersey: Pearson education.

35. Lesabe, R.A. (2007). A qualitative exploration of employees' views on organizational commitment, SA Journal of Human Resource Management, 5 (1), pp. 35-44.

36. Lumley, E. (2010). Exploring the relationship between career anchors, job satisfaction and organizational commitment. Unpublished master's dissertation, Department of Industrial and Organizational Psychology, University of South Africa, Pretoria.

37. Malhotra, N., Budhwar, P. and Prowse, P. (2007). Linking Rewards to Commitment: An Empirical Investigation of Four UK Call Centres, International Journal of Human Resource Management, 18 (12), pp. 2095-2128.

38. Maree, K., Pieterson, J. (2007). First Steps in Research. Pretoria: Van Schaik Publishers.

39. McMillan, J.H. (2008). Educational Research, Fundamentals for the Consumer. USA: Pearson Education.

40. Meyer, J.P. \& Allen, N.J. (1997). Commitment in the Workplace: Theory, Research and Application. Thousand Oaks, California: Sage Publications.

41. Meyer, J.P., Allen, N.J. and Smith, C.A. (1993). Commitment to Organizations and Occupations: Extension and Test of a Three-Component Conception, Journal of Applied Psychology, 78, pp. 538-551.

42. Miller, D. \& Lee, J. (2001). The people make the process: commitment to employees, decision-making and performance, Journal of Management, 27, pp. 163-189.

43. Miller, K. (2003). Values, attitudes and job satisfaction. In Robbins, S.P., Odendaal A. \&Roodt, G. (eds), Organizational Behavior: Global and Southern African Perspectives. Cape Town: Pearson Education South Africa.

44. Morrow, P.C. (1993). The Theory and Measurement of Work Commitment. Greenwich, CT: Jai.

45. Mowday, R.T., Porter, L.W. and Steers, R.M. (1982). Employee-organization linkages: The psychology of commitment, absenteeism and turnover. New York: Academic Press.

46. Naong, M.N. (2010). Justification for skills transfer and validating a specific developed measuring instrument, African Journal of Business Management, 4 (6), pp. 1085-1094.

47. Naong, M.N.( 2014). The Impact of Skills-Development Training on Lower-Level Employee's Motivation and Job Satisfaction - A Case-Study of Five South African Companies, Mediterranean Journal of Social Sciences, 5 (20), pp. 369-380.

48. Newman, A., Thanacoody, R. \& Hui, W. (2011). The Impact of Employee Perceptions of Training on Organizational Commitment and Turnover Intentions: A Study of Multinationals in the Chinese Service Sector. Available at: https://eprints.mdx.ac.uk/4706/1/Thanacoody-Impact_of_employee_perceptions....pdf.

49. Ng, T.W.H., Sorensen, K.L. (2008). Toward a further understanding of the relationships, Organization Management, 33 (3), pp. 243-268.

50. Owens, P.L. (2006). One More Reason Not to Cut your Training Budget: The Relationship between Training and Organizational Outcomes, Public Personnel Management, 35 (2), pp. 163-172.

51. Riaz, A., Idrees, R.N. and Imran, A. (2013). Employees' Belief Regarding Training Benefits and Organizational Commitment: A Case in Banking Sector of Pakistan, Middle-East Journal of Scientific Research, 16 (3), pp. $310-318$. 
52. Roodt, G. (2004). Concept redundancy and contamination in employee commitment research: Current problems and future directions, South African Journal of Industrial Psychology, 30 (1), pp. 82-90.

53. Rousseau, D.M. (1995). Psychological Contracts in Organizations. Thousand Oaks, CA: Sage

54. Satisfaction and Turnover Intentions of Public Employees? The American Review of Public Administration, 38 (2), pp. 149-166.

55. Sheri-Lynne, Leskiw and Parbudyal Singh (2007). Leadership development: learning from best practices, Leadership and Organization Development Journal, 28 (5).

56. Swanepoel, B. (2000). South African Human Resource Management Series and Practice. 2nd Edition. Johannesburg: Juta \& Co.

57. Van Rensburg, K.J. (2004). A predictive model of employee commitment in an organization striving to become world-class. Doctoral thesis (Unpublished). Rand Afrikaans University. Johannesburg.

58. Vroom, V.H. (1964). Work and motivation. San Francisco, CA: Jossey-Bass Workplace health, safety and welfare. Workplace (Health, Safety and Welfare)

59. Werner, A. (2007). Organizational Behavior: a Contemporary South African Perspective. Pretoria: Van Schaik.

60. White, M. \& Bryson, A. (2013). Positive employee attitudes: how much human resource management do you need? Human Relations, 66 (3), pp. 385-406.

61. Yamnill, S. \& McClean, G.N. (2001). Theories Supporting Transfer of Training, Human Resource Quarterly, 12 (2), pp. 195-208.

62. Yong, A.G. \& Pearce, S. (2013). A Beginner's Guide to Factor Analysis: Focusing on Exploratory Factor Analysis, Tutorials in Quantitative Methods for Psychology, 9 (2), pp. 79-94. 